\title{
Experimental Investigation on an Absorption Refrigerator Driven by Solar Cells
}

\author{
Zi-Jie Chien, ${ }^{1}$ Hung-Pin Cho, ${ }^{2}$ Ching-Song Jwo, ${ }^{1}$ Chao-Chun Chien, ${ }^{1}$ \\ Sih-Li Chen, ${ }^{2}$ and Yen-Lin Chen ${ }^{3}$ \\ ${ }^{1}$ Department of Energy and Refrigerating Air-Conditioning Engineering, National Taipei University of Technology, \\ Taipei 10608, Taiwan \\ ${ }^{2}$ Department of Mechanical Engineering, National Taiwan University, Taipei 10617, Taiwan \\ ${ }^{3}$ Department of Computer Science and Information Engineering, National Taipei University of Technology, Taipei 10608, Taiwan
}

Correspondence should be addressed to Yen-Lin Chen; ylchen@ntut.edu.tw

Received 23 November 2012; Accepted 7 January 2013

Academic Editor: Ho Chang

Copyright (C) $2013 \mathrm{Zi}$-Jie Chien et al. This is an open access article distributed under the Creative Commons Attribution License, which permits unrestricted use, distribution, and reproduction in any medium, provided the original work is properly cited.

\begin{abstract}
This experiment is to study an absorption refrigerator driven by solar cells. Hand-held or carried in vehicle can be powered by solar energy in places without power. In the evenings or rainy days, it is powered by storage battery, and it can be directly powered by alternating current (AC) power supply if available, and the storage battery can be charged full as a backup supply. The proposed system was tested by the alternation of solar irradiance 550 to $700 \mathrm{~W} / \mathrm{m}^{2}$ as solar energy and $500 \mathrm{ml}$ ambient temperature water as cooling load. After 160 minutes, the proposal refrigerator can maintain the temperature at $5-8^{\circ} \mathrm{C}$, and the coefficient of performance (COP) of $\mathrm{NH}_{3}-\mathrm{H}_{2} \mathrm{O}$ absorption refrigeration system is about 0.25 . Therefore, this system can be expected to be used in remote areas for refrigeration of food and beverages in outdoor activities in remote and desert areas or long-distance road transportation of food or low temperature refrigeration of vaccine to avoid the deterioration of the food or the vaccines.
\end{abstract}

\section{Introduction}

Nowadays the economic development has resulted in a lot of energy exploitation, and the oil reservation becomes exhausted. It will run out within less than 50 years, causing the so-called energy crisis. Overexploitation has also caused increasingly serious global warming problem. Many advanced countries in the world today take the lead in promoting the research and development of alternative energy such as wind energy, solar energy, and biomass energy. The importance of research and development on green energy has attracted much attention. Although their cost is high, continuous research and development will achieve the stable, easy-to-use, and reasonably priced alternative energy in some day. This is a road we must take for the survival of humanity.

In literature, there are numerous studies in absorption refrigerators. Bansal and Martin [1] have compared the performance of vapor compression and thermoelectric and absorption refrigerators. Dai et al. [2] have experimental investigation on a thermoelectric refrigerator driven by solar cells. Riffat and Qiu [3] conducted comparative investigation of thermoelectric airconditioners versus vapor compression and absorption airconditioners. Fernández-Seara and Vázquez [4] develop control algorithm of the optimal generation temperature $\mathrm{NH}_{3}-\mathrm{H}_{2} \mathrm{O}$ absorption refrigeration systems. Göktun and Deha Er [5] utilize a solar-assisted combined absorption-vapor compression system for air conditioning and space heating. Wu et al. [6] propose optimization solar absorption refrigerator. One of the most promising schemes is the utilization of an absorption refrigeration cycle with solar energy serving as the source of heat to operate the generator. Yaxiu et al. [7] conduct experimental research on a new solar pump-free lithium bromide absorption refrigeration system with a second generator the maximum coefficient of performance (COP) approaches 0.787. Hwang [8] potential energy benefits of integrated refrigeration system with microturbine and absorption chiller. Fathi et al. [9] research an irreversible thermodynamic model for solar absorption refrigerator. Şencan [10] uses artificial neural networks performance of ammonia-water refrigeration systems. 


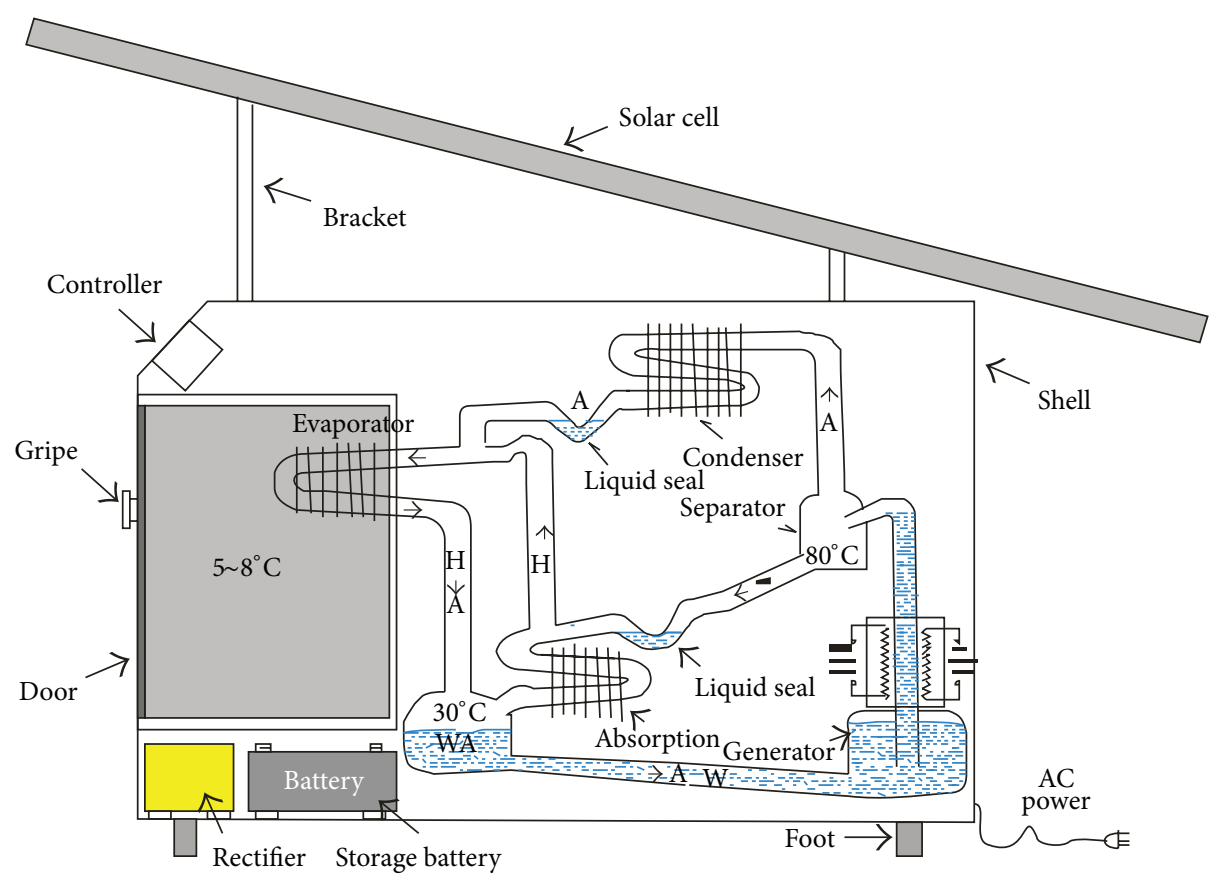

FIgURE 1: Experimental equipment of absorption refrigerator.

AL-Hawaj and AL-Mutairi [11] cogeneration scheme comprising a combined cycle power plant (CCPP) with an absorption chiller used for space cooling is studied. Sieres and Fernández-Seara [12] experimental investigation of mass transfer performance with some random packings for ammonia rectification in ammonia-water absorption. Sozen et al. [13-15] have improved performance of absorption refrigeration system by using triple-pressure level. Said et al. $[16,17]$ indicate that continuously operating solar-powered aqua-ammonia absorption system with refrigerant storage is the most suitable alternative design for an uninterrupted supply of cooling effect. Rothwell et al. [18, 19] developed a coupled solar wing-magnetosphere-ionosphere model for determining the ionospheric penetration electric field. Bilgili [20] has conducted hourly simulation and performance of solar electron-vapor compression refrigeration system. Colonna and Gabrielli [21] used a new solar pump-free lithium bromide absorption refrigeration system with a second generator. Odeh [22] proposed a unified model of solar thermal electric generation systems. Al-Alili et al. [23, 24] use a solar powered absorption cycle under Abu Dhabi's weather conditions. Monné et al. [25] developed a stationary analysis of a solar $\mathrm{LiBr}-\mathrm{H}_{2} \mathrm{O}$ absorption refrigeration system. Alvares and Trepp [26] developed a simulation of a solar driven aqua-ammonia absorption refrigeration system part 1 : mathematical description and system optimization. LeBreux et al. [27] proposed a control method of a hybrid solar/electric thermal energy storage system.

In summary of the previously mentioned literature review, the proposed small-scale absorption refrigeration system driven by solar power is unprecedented. This study proposes an absorption refrigeration system using refrigerant
$\mathrm{NH}_{3}$ and absorbent $\mathrm{H}_{2} \mathrm{O}$. As being an environmentally friendly refrigeration system, it is powered by solar cells. The successful development of the proposed system can solve problems such as the long-distance transportation of medical vaccines and the refrigeration of food and beverages in remote areas lacking power supply.

\section{Experiment and Methodology}

2.1. The Proposed Experimental System. As shown in Figure 1, the energy of the absorption refrigeration is supported by $18 \mathrm{~V}$ of direct electricity from solar cells and the capacity of cold storage covers in 30 liters. Power consumption covers $1.2 \mathrm{KWH} / 24 \mathrm{~h}$ with filling 70 grams of $\mathrm{NH}_{3}$ refrigerant. The experimental system is the $\mathrm{NH}_{3}-\mathrm{H}_{2} \mathrm{O}$ absorption refrigeration system consisting of solar cells, controller, storage battery, rectifier, and absorption refrigerator. In the daytime, the solar cells receive solar energy to power the absorption refrigerator. When too much energy is supplied, the controller will store the excess energy in the storage battery. When the solar power is insufficient or unavailable at night or in cloudy days, it depends on the storage battery for power supply. The storage battery can be charged in places with AC power supply as a backup power source. In order to achieve better power generation efficiency of the solar panel, it will always be placed towards the sun. The shape between solar panel and horizontal line becomes tilt angle. The optimal angle for tilted surface was calculated by searching for the values of which the daily total solar radiation was at a maximum for a specific period. The yearly average optimal tilt angles for a south-facing solar collector about 31.21 to 34.31 degrees [28]. Therefore, the tilt angle of the study is determined as $35^{\circ} \mathrm{C}$. 


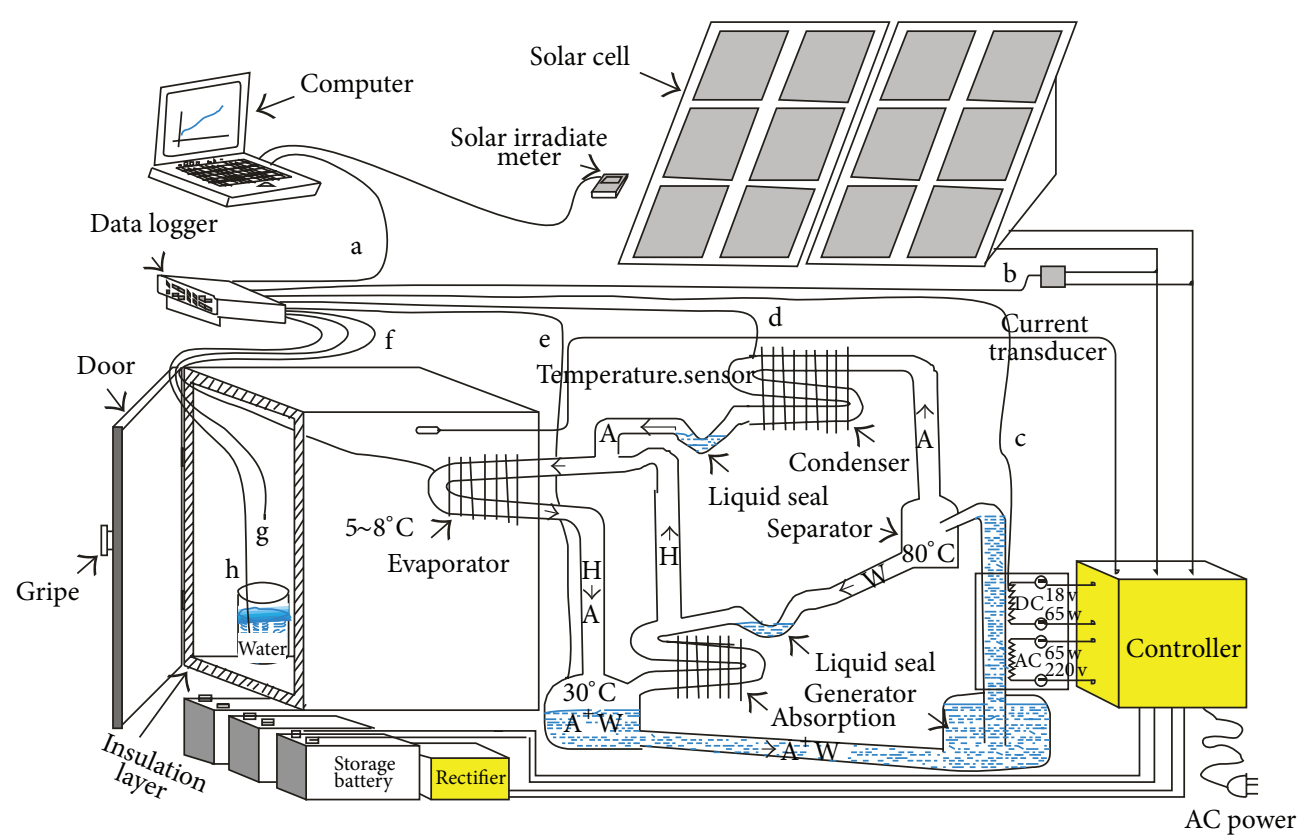

FIGURE 2: Distribution of various measurement points of the experimental system.

TABLE 1: Specifications of solar cell driven absorption refrigerator.

\begin{tabular}{|c|c|c|}
\hline Items & Description & Value \\
\hline \multirow{4}{*}{ Array of solar cell } & The area of solar cell, $A$ & $1.78 \mathrm{~m}^{-2}$ \\
\hline & Max output power of solar cell, $P_{\max }$ & $184 \mathrm{~W}$ \\
\hline & Solar irradiance, $S$ & $800 \mathrm{Wm}^{-2}$ \\
\hline & The efficiency of energy conversion from solar energy to electric power & 0.14 \\
\hline \multirow{7}{*}{ Storage battery } & Stands for the battery storage capacity & $100 \mathrm{AH}$ \\
\hline & Electric consumption & $22 \mathrm{AH} /$ day \\
\hline & The number of day without sunshine & 2 days \\
\hline & The maximum degree of electric discharge & 0.8 \\
\hline & The efficiency of the storage battery & 0.86 \\
\hline & The loss coefficient of the circuit & 0.05 \\
\hline & The correction coefficient of temperature & 0.9 \\
\hline \multirow{3}{*}{ Absorption refrigerator } & Refrigerant & $\mathrm{NH}_{3}$ \\
\hline & Absorption & $\mathrm{H}_{2} \mathrm{O}$ \\
\hline & Power & $65 \mathrm{~W}, 17 \mathrm{~V}$ \\
\hline
\end{tabular}

2.2. The Proposed Experimental Method and Procedures. The location of installation of various measurement points, data acquisition device, and personal computer connection of the experimental system are shown in Figure 2. We applied a data logger and a computer to collect six points of data that set sample time to two minutes. These six points include four temperatures points (i.e., ambient temperature, generator temperature, cooled side temperature, and water temperature), one current of solar cell, and one solar irradiate.

We conduct the no-load test at first and then the loaded tests while gradually recording the experimental results. The major test of this study is to test the performance and feasibility of running the absorption refrigeration system by using the power generated by solar cells during the day.
Regarding the backup battery power supply performance and the charging system's material characteristics are not discussed in this study.

The experimental system's solar cells and storage battery, absorption refrigerator specifications are shown in Table 1. The maximum power capacity of the solar cells is $184 \mathrm{~W}$. The maximum storage capacity of the storage cell is $100 \mathrm{Ah}$. The refrigerant of the absorption refrigeration system is $\mathrm{NH}_{3}$ and the absorbent is $\mathrm{H}_{2} \mathrm{O}$. The input power voltage is $17 \mathrm{~V}$, and the input power is $65 \mathrm{~W}$.

\section{Theoretical Formulation for Transformer}

The performance of the solar cells and absorption refrigeration system can be obtained by the following equation. 


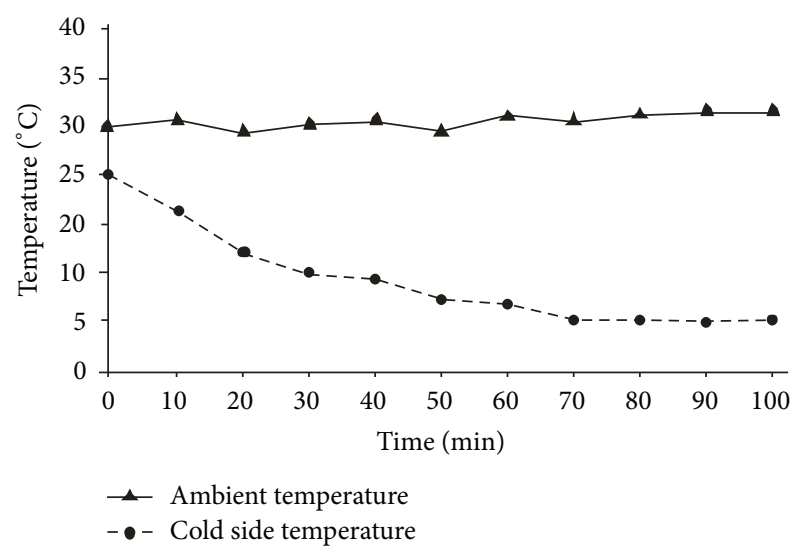

FIGURE 3: The changes in the ambient temperature and cold side temperature under sunlight.

The output of power supply capacity of solar cells [2] is calculated by the following equation:

$$
P_{\text {solar }}=S A \eta_{P V}
$$

where $P_{\text {solar }}$ is power supply capacity of solar cells $(\mathrm{W}), S$ is solar irradiance $\left(\mathrm{W} / \mathrm{m}^{2}\right), A$ is the area of Solar array to receive solar irradiation $\left(\mathrm{m}^{2}\right)$, and $\eta_{P V}$ is the efficiency of energy conversion from solar energy to electric power.

According (1), the power generation of the solar panel is proportional to the solar irradiance.

The coefficient of performance (COP) of absorption refrigeration system [3] is

$$
\begin{aligned}
\text { COP } & =\frac{\text { Desired output }}{\text { Required input }} \\
& =\frac{Q_{L}}{Q_{\text {gen }}}=\left(1-\frac{T_{a}}{T_{g}}\right)\left(\frac{T_{r}}{T_{a}-T_{r}}\right),
\end{aligned}
$$

where $Q_{\text {gen }}$ is heat energy given to the generator in absorption (W), $Q_{L}$ is heat energy that evaporator absorbs from the cooled space (W), $T_{a}$ is the ambient temperature $(\mathrm{K}), T_{g}$ is the generator temperature $(\mathrm{K})$, and $T_{r}$ is the cooled side temperature $(\mathrm{K})$.

We could get several trends from (2); namely, as $T_{g}$ increases, the COP increases; as $T_{r}$ increases, the COP increases; as $T_{a}$ increases, the COP decreases.

\section{Results and Discussion}

In the no-load test of the absorption refrigeration system, we conducted the 100-minute experimental test and record the experimental results in Figures 3-5 before carrying out the 200-minute loaded experimental test. The test results were recorded in Figures 6-8, and the theoretical relationship equations were applied for analysis to get the following:

Under the sun, the ambient temperature is $30^{\circ} \mathrm{C}$, and the cold side temperature is $24^{\circ} \mathrm{C}$. The trend of cold side temperature is shown in Figure 3. When solar panels are under the sunlight, the absorption refrigeration system will start to

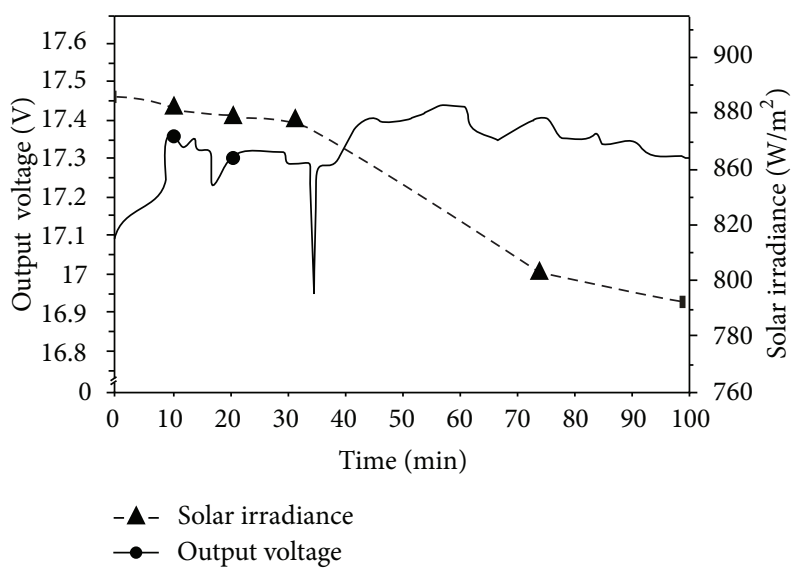

FIGURE 4: The changes in solar irradiance and output voltage under sunlight.

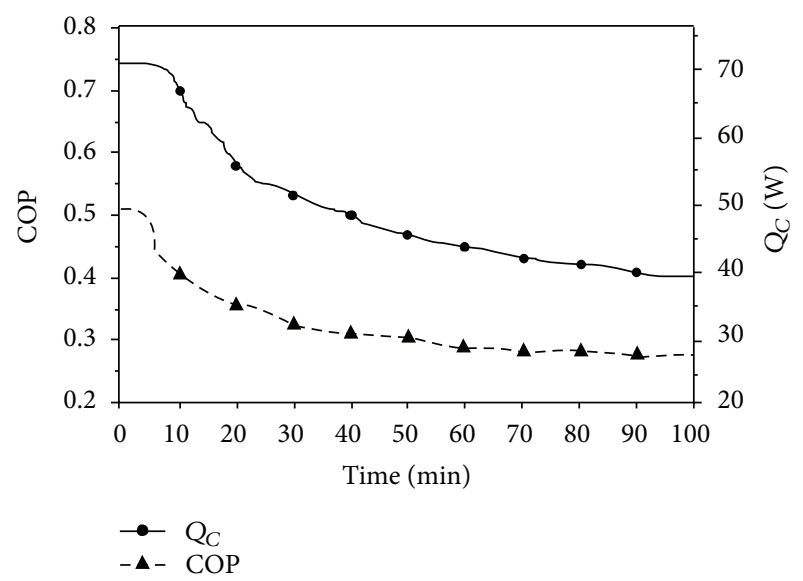

FIGURE 5: The changes in refrigeration system COP and refrigerating capacity $Q_{C}$, under the sunlight.

run. It can be apparently found that the cold side temperature slowly decreases. After running for 30 minutes, the cold side temperature dropped to $10^{\circ} \mathrm{C}$. After 70 -minute running, the cold side temperature dropped to $5^{\circ} \mathrm{C}$.

As shown in Figure 4, due to changes in solar irradiance, the power supply $880 \mathrm{~W} / \mathrm{m}^{2}$ dropped to $770 \mathrm{~W} / \mathrm{m}^{2}$ after 90 minutes. The solar panel output voltage remains between 16.9 and $17.5 \mathrm{~V}$. At the moment of 35 minutes, the sunlight covered by clouds leads to the deep drop of voltage. However, to reveal the real experimental situation, we still keep these data unaltered in Figure 4.

As shown in Figure 5, when the ambient temperature remains unchanged, the cold side temperature dramatically dropped to below $5^{\circ} \mathrm{C}$ after running for 70 minutes. Due to the decrease in cold side temperature, the absorption refrigeration system COP dropped from 0.5 to 0.28 , the refrigeration system cooling capacity dropped from $69 \mathrm{~W}$ to $39 \mathrm{~W}$, proving that the cooling capacity will decrease over declining cold side temperature and its COP will also decrease. 


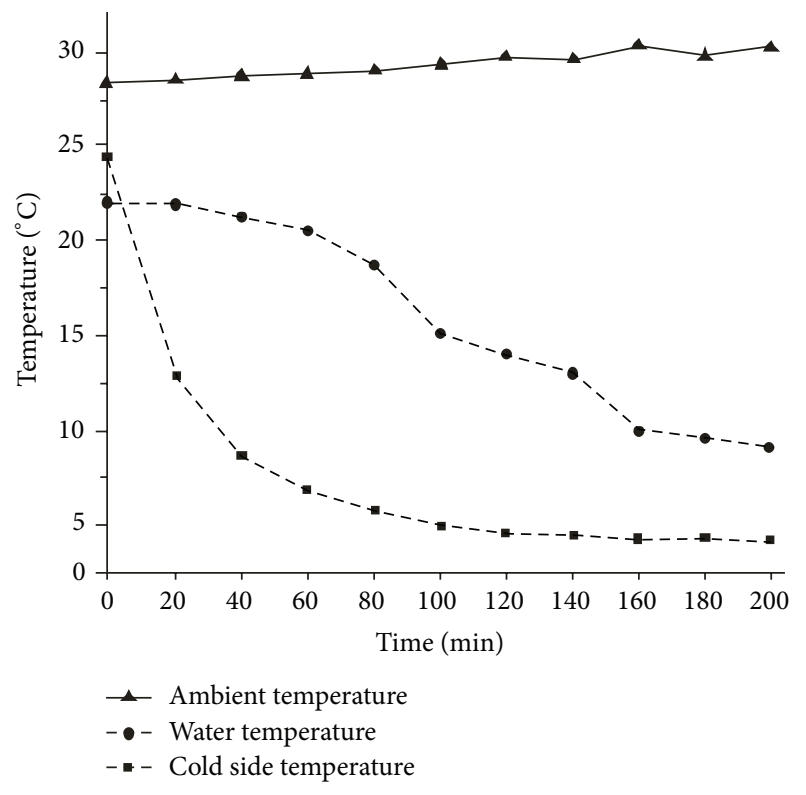

FIGURE 6: The changes in the temperature of $500 \mathrm{~mL}$ water placed inside, under the sunlight.

The loaded test was to place the $500 \mathrm{~mL}$ room temperature water inside as shown in Figure 6. When the testing ambient temperature was $27^{\circ} \mathrm{C}$, the cold side temperature slowly dropped to $24^{\circ} \mathrm{C}$. After running for 20 minutes, the cold side temperature dropped to $13^{\circ} \mathrm{C}$, after running for 100 minutes, the cold side temperature dropped to $5^{\circ} \mathrm{C}$. The water temperature dropped very slowly from the beginning temperature of $24^{\circ} \mathrm{C}$. After 80 minutes, the water temperature apparently dropped. After 200 minutes, the water temperature dropped to $8^{\circ} \mathrm{C}$ and would be even lower if the system was still running on.

The study investigates the alternation of solar irradiance measured every two minutes while driving on the high way, which results in a sudden transform of solar irradiance. The solar irradiance and output voltage changes are shown in Figure 7. When the solar irradiance is 550 to $700 \mathrm{~W} / \mathrm{m}^{2}$, the output voltage is about 16 to $17.2 \mathrm{~V}$. In other words, when the solar irradiance rate is greater, the solar power generation will be greater. According to (1), the power generation of the solar panel is proportional to the solar irradiance. The results confirm the phenomenon given in (1).

As shown in Figure 8, under the sunlight, $500 \mathrm{~mL}$ water of room temperature is placed inside. At 0-60 minutes, water temperature from 24 to $21^{\circ} \mathrm{C}$, and cold side temperature from 24 to $8^{\circ} \mathrm{C}$ as shown in Figure 6, cooling load is high. COP drops rapidly from 0.38 to 0.22 , and the refrigerating capacity drops rapidly from 65 to $48 \mathrm{~W}$. At $60-160$ minutes, water temperature from 21 to $12^{\circ} \mathrm{C}$, and cold side temperature from 8 to $5^{\circ} \mathrm{C}$ mean cooling load decreases but it is still high, the system COP is around 0.22 and the refrigerating capacity is about $45 \mathrm{~W}$. At 160-200 minutes, the water temperature from $12^{\circ} \mathrm{C}$ to $10^{\circ} \mathrm{C}$, and cold side temperature of $5^{\circ} \mathrm{C}$, mean cooling load is low as shown in Figure 6 and the system COP increases from 0.22 to 0.28 .

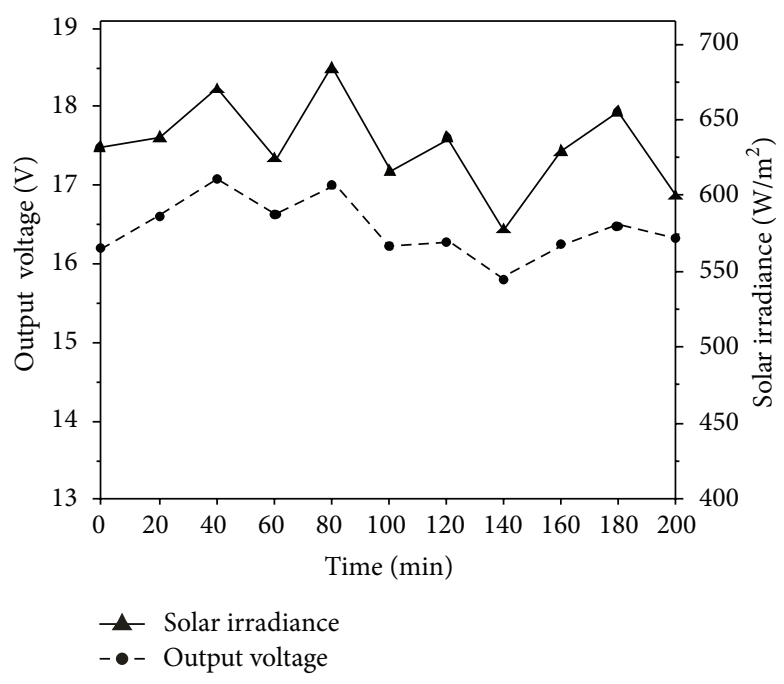

FIGURE 7: The changes in output voltage and solar irradiance, when $500 \mathrm{~mL}$ was placed inside, under the sunlight.

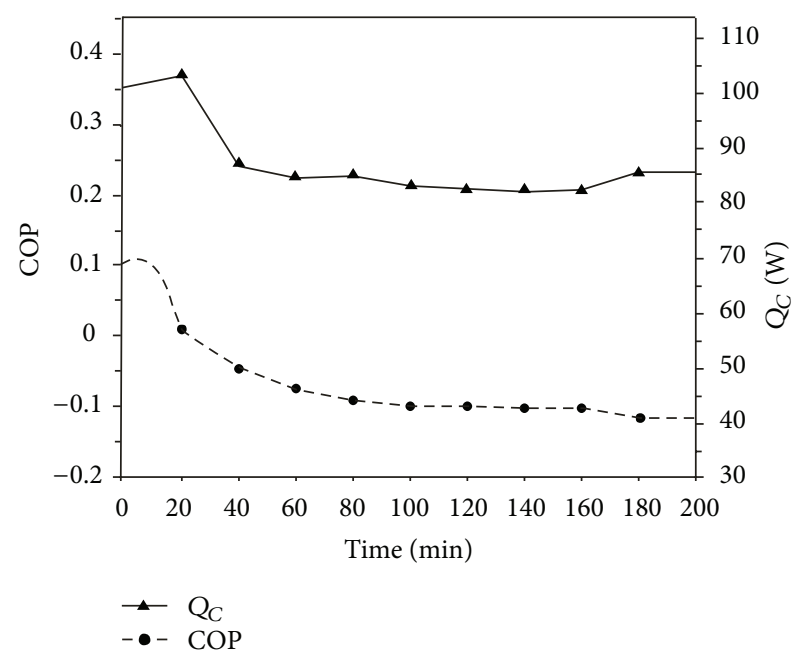

FIGURE 8: The changes in refrigeration system COP and refrigerating capacity $Q_{C}$, when $500 \mathrm{~mL}$ water of room temperature is placed inside, under the sunlight.

\section{Conclusions}

In summary of the experimental research results, the solar energy can supply energy for the running of the absorption refrigerator. The outdoor activities and works, such as mineral development, road construction, and other occasions, can be adopted. It is designed in order to meet the outdoor usage requirements as lightweight, low price, and day and night usage. According to the experimental results, the alternation of solar irradiance 550 to $700 \mathrm{~W} / \mathrm{m}^{2}$ and $500 \mathrm{~mL}$ ambient temperature water as cooling load. After 160 minutes, the proposal refrigerator can maintain the temperature at $5-8^{\circ} \mathrm{C}$, and the $\mathrm{COP}$ is about 0.25 . 


\section{Acknowledgments}

This project is financially sponsored by the National Science Council under Grants NSC-101-2622-E-027-025-CC3, NSC101-2219-E-027-006, and NSC-99-2221-E-027-069-MY3 and Fumin Education Foundation.

\section{References}

[1] P. K. Bansal and A. Martin, "Comparative study of vapour compression, thermoelectric and absorption refrigerators," International Journal of Energy Research, vol. 24, no. 2, pp. 93-107, 2000.

[2] Y. J. Dai, R. Z. Wang, and L. Ni, "Experimental investigation on a thermoelectric refrigerator driven by solar cells," Renewable Energy, vol. 28, no. 6, pp. 949-959, 2003.

[3] S. B. Riffat and G. Qiu, "Comparative investigation of thermoelectric air-conditioners versus vapour compression and absorption air-conditioners," Applied Thermal Engineering, vol. 24, no. 14-15, pp. 1979-1993, 2004.

[4] J. Fernández-Seara and M. Vázquez, "Study and control of the optimal generation temperature in $\mathrm{NH}_{3}-\mathrm{H}_{2} \mathrm{O}$ absorption refrigeration systems," Applied Thermal Engineering, vol. 21, pp. 343-353, 2001.

[5] S. Göktun and İ. Deha Er, "The optimum performance of a solar-assisted combined absorption-vapor compression system for air conditioning and space heating," Solar Energy, vol. 71, no. 3, pp. 213-216, 2001.

[6] C. Wu, L. Chen, and F. Sun, "Optimization of solar absorption refrigerator," Applied Thermal Engineering, vol. 17, no. 2, pp. 203208, 1997.

[7] G. Yaxiu, W. Yuyuan, and K. Xin, "Experimental research on a new solar pump-free lithium bromide absorption refrigeration system with a second generator," Solar Energy, vol. 82, no. 1, pp. 33-42, 2008.

[8] Y. Hwang, "Potential energy benefits of integrated refrigeration system with microturbine and absorption chiller," International Journal of Refrigeration, vol. 27, no. 8, pp. 816-829, 2004.

[9] R. Fathi, C. Guemimi, and S. Ouaskit, "An irreversible thermodynamic model for solar absorption refrigerator," Renewable Energy, vol. 29, no. 8, pp. 1349-1365, 2004.

[10] A. Şencan, "Performance of ammonia-water refrigeration systems using artificial neural networks," Renewable Energy, vol. 32, no. 2, pp. 314-328, 2007.

[11] O. M. AL-Hawaj and H. AL-Mutairi, "A combined power cycle with absorption air conditioning," Energy, vol. 32, no. 6, pp. 971982, 2007.

[12] J. Sieres and J. Fernández-Seara, "Experimental investigation of mass transfer performance with some random packings for ammonia rectification in ammonia-water absorption refrigeration systems," International Journal of Thermal Sciences, vol. 46, no. 7, pp. 699-706, 2007.

[13] A. Sözen and M. Özalp, "Performance improvement of absorption refrigeration system using triple-pressure-level," Applied Thermal Engineering, vol. 23, no. 13, pp. 1577-1593, 2003.

[14] Y. He and G. Chen, "Experimental study on an absorption refrigeration system at low temperatures," International Journal of Thermal Sciences, vol. 46, no. 3, pp. 294-299, 2007.

[15] J. V. C. Vargas, J. C. Ordonez, E. Dilay, and J. A. R. Parise, "Modeling, simulation and optimization of a solar collector driven water heating and absorption cooling plant," Solar Energy, vol. 83, no. 8, pp. 1232-1244, 2009.
[16] G. Pei, J. Li, and J. Ji, "Analysis of low temperature solar thermal electric generation using regenerative organic rankine cycle," Applied Thermal Engineering, vol. 30, no. 8-9, pp. 998-1004, 2010.

[17] S. A. M. Said, M. A. I. El-Shaarawi, and M. U. Siddiqui, "Alternative designs for a $24-\mathrm{h}$ operating solar-powered absorption refrigeration technology," International Journal of Refrigeration, vol. 35, no. 7, pp. 1967-1977, 2012.

[18] P. L. Rothwell and J. R. Jasperse, "A coupled solar windmagnetosphere-ionosphere model for determining the ionospheric penetration electric field," Journal of Atmospheric and Solar-Terrestrial Physics, vol. 69, no. 10-11, pp. 1127-1134, 2007.

[19] N. Molero-Villar, J. M. Cejudo-López, F. Domínguez-Muñoz, and A. Carrillo-Andrés, "A comparison of solar absorption system configurations," Solar Energy, vol. 86, no. 1, pp. 242-252, 2012.

[20] M. Bilgili, "Hourly simulation and performance of solar electric-vapor compression refrigeration system," Solar Energy, vol. 85, no. 11, pp. 2720-2731, 2011.

[21] P. Colonna and S. Gabrielli, "Industrial trigeneration using ammonia-water absorption refrigeration systems (AAR)," Applied Thermal Engineering, vol. 23, no. 4, pp. 381-396, 2003.

[22] S. D. Odeh, "Unified model of solar thermal electric generation systems," Renewable Energy, vol. 28, no. 5, pp. 755-767, 2003.

[23] A. Al-Alili, Y. Hwang, R. Radermacher, and I. Kubo, "Optimization of a solar powered absorption cycle under Abu Dhabi's weather conditions," Solar Energy, vol. 84, no. 12, pp. 20342040, 2010.

[24] A. Lecuona, R. Ventas, M. Venegas, A. Zacarías, and R. Salgado, "Optimum hot water temperature for absorption solar cooling," Solar Energy, vol. 83, no. 10, pp. 1806-1814, 2009.

[25] C. Monné, S. Alonso, F. Palacín, and J. Guallar, "Stationary analysis of a solar $\mathrm{LiBr}-\mathrm{H}_{2} \mathrm{O}$ absorption refrigeration system," International Journal of Refrigeration, vol. 34, no. 2, pp. 518-526, 2011.

[26] S. G. Alvares and C. Trepp, "Simulation of a solar driven aquaammonia absorption refrigeration system-part 1: mathematical description and system optimization," International Journal of Refrigeration, vol. 10, no. 1, pp. 40-48, 1987.

[27] M. LeBreux, M. Lacroix, and G. Lachiver, "Control of a hybrid solar/electric thermal energy storage system," International Journal of Thermal Sciences, vol. 48, no. 3, pp. 645-654, 2009.

[28] K. Bakirc, "General models for optimum tilt angles of solar panels: Turkey case study," Renewable and Sustainable Energy Reviews, vol. 16, no. 8, pp. 6149-6159, 2012. 

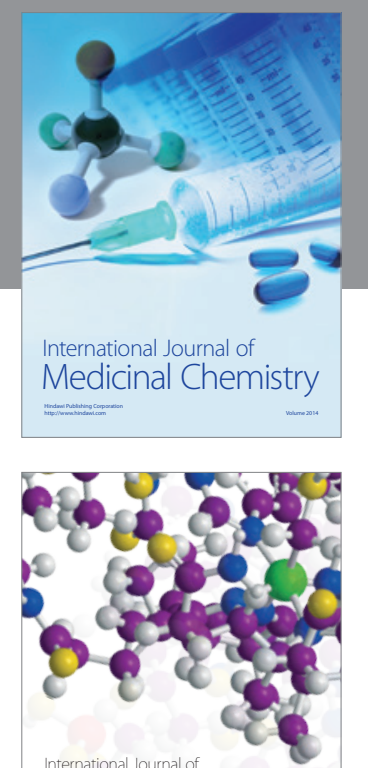

\section{Carbohydrate} Chemistry

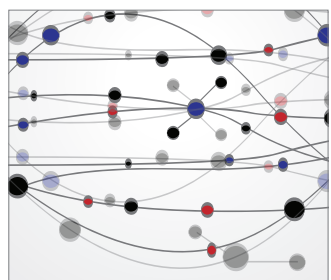

The Scientific World Journal
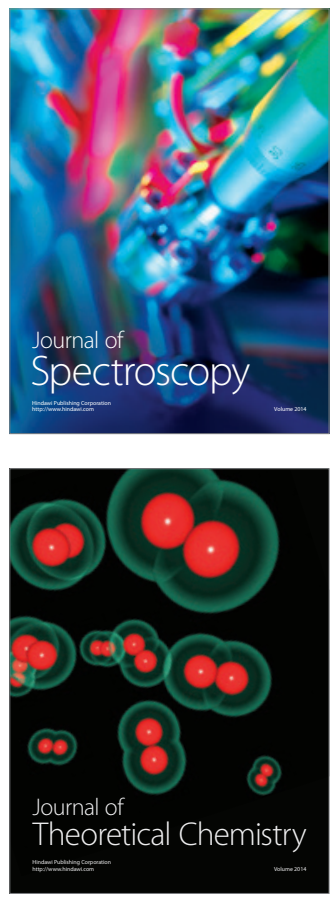
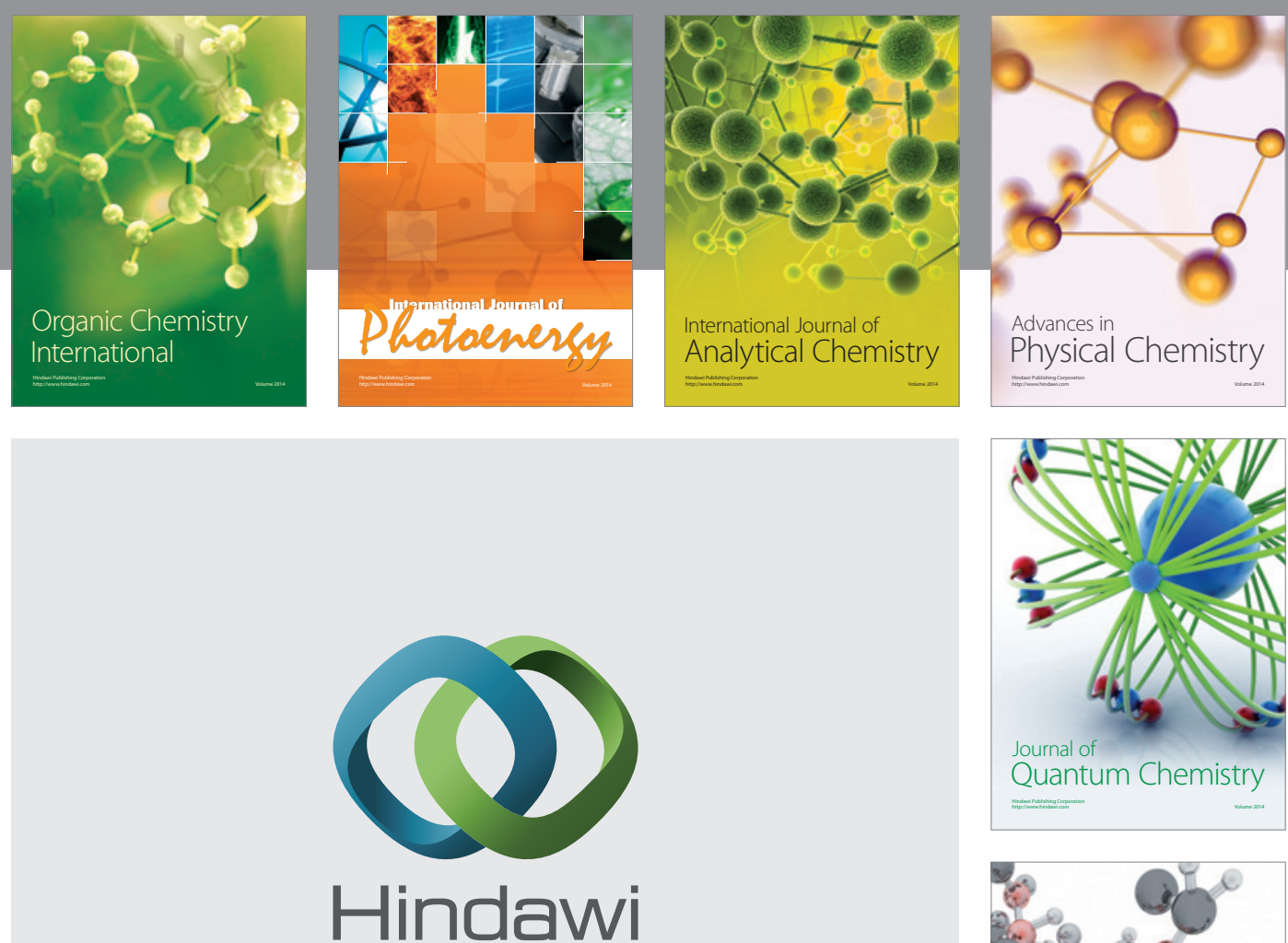

Submit your manuscripts at

http://www.hindawi.com

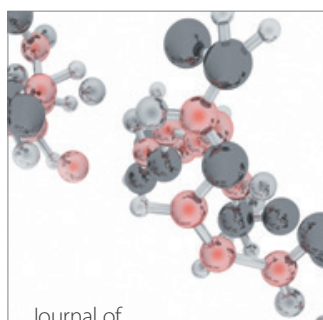

Analytical Methods

in Chemistry

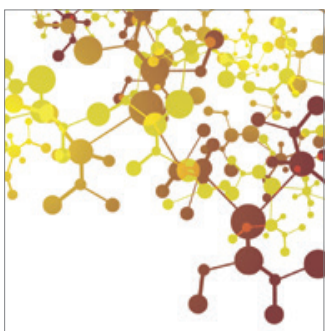

Journal of

Applied Chemistry

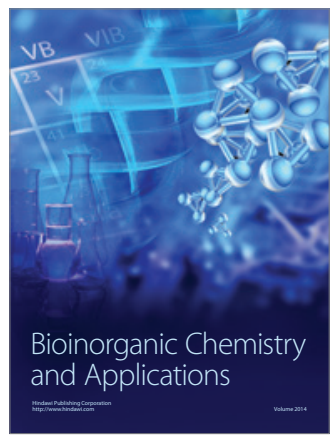

Inorganic Chemistry
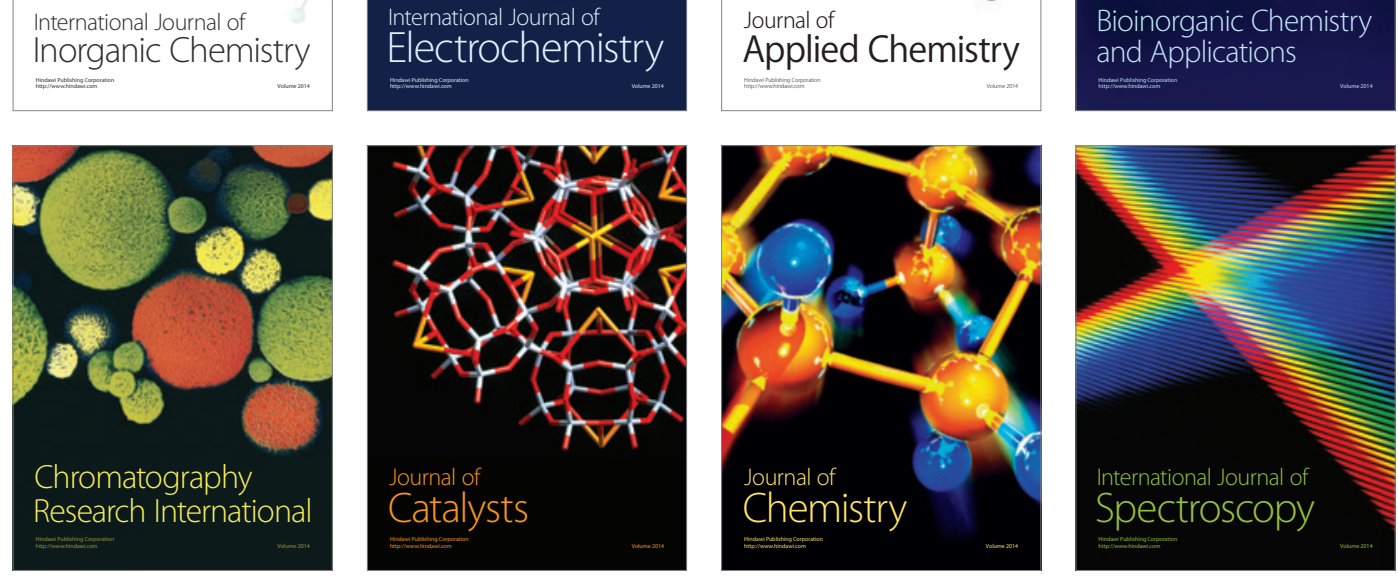